\title{
CROSSROADS AND MEETINGS
}

\author{
PRELUDE
}

Anca GiURChescu

Kornblomsvej 8. Ith, 2300 Copenhagen S, Denmark

My aim was to reconstruct our meetings with Martin as rigorously and honestly as I can, but I had to admit that in the field of research history such attempts are doomed to failure. That is why I cannot but take the responsibility for all the omissions and forgotten details. They are inevitable when we recollect past events, especially if they happened 50 years ago.

I met Martin first in 1963, and till 1978 on several occasions. Our meetings happened in the period of time when Romanian ethnochoreology reached adulthood. So my memories about Martin are closely intertwined with my memories about the establishment of the theoretical and methodological framework of our folk dance research in the Institute of Folklore and Ethnography in Bucharest.

\section{VARIATIONS ON THE THEME}

Perhaps it may seem that to go back 50 years into the past does not make much sense or have much relevancy. But, recalling my meetings with Martin helped me to discover their significance in my life. They led me out from the scientific isolation which was intruded on us by the policy. This recollection assists me to understand that the way Martin created the theoretical and methodological basis of the Hungarian ethnochoreology had a great impact on the Romanian folk dance research. At least in certain periods. Many of the research projects planned by Martin are vital and timely even in our days in ethnochoreology. I would like to believe that our long and exciting discussions during our meetings contributed to the formation of at least some of those research directions which he created. I am still proud of it that Martin gifted me with his friendship. I was impressed with his profound knowledge and rich experience in dance research. It was the result of his 
thorough and broad scientific education crowned by his passion for research and practical embodiment of the folk dances. In my view, his exceptional scientific achievement and his personal intellectual strength was fuelled by this passion. And what is more, his scholarly virtues coupled with huge human generosity and humanism. He was blessed with almost excessive modesty and with the ability to approach people with great empathy.

\section{OUR FIRST MEETING}

My first meeting with Hungarian ethnochoreology took place on the dry field of structural analysis of dance forms in the framework of the International Folk Music Council (later International Council for Traditional Music) in Zlín (that time Gottwaldov, Czech Republic). This meeting was dedicated to the establishment of the Study Group on Dance Terminology aiming to unify the terminology of dance analysis. György Martin and Ernö Pesovár also participated and presented their ideas about the theme. Each participant in this small group came with their own system of analysis developed in various European dance regions where he/she made research. We became friends with Martin on this platform during the series of such meetings.

The method of communication in this narrow group of ethnochoreologists was different from that of the conferences, seminars, round tables elsewhere. We had free debates by identifying the basic problems, listing the arguments and supporting them by practical examples and theories. Such discussions did not lead to confusion, because each of these meetings ended by a written conclusion approved by the majority of the participants. The dialogue between us continued in correspondence. These discussions held on different scenes and in different countries resulted in the discovery of the grammar (the grammatical structure) of the traditional dances. It turned out to be an inevitable set of tools for the research of dances and other bodily expressions.

Our meetings in the framework of the Study Group of Dance Terminology led me to the deeper understanding of Martin's character and personality. As I realised, he was the prototype of the very committed researcher, who was eager to get new knowledge from every kinds of sources. So, our cooperation began with the exchange of scientific publications. Any place we happened to be, first he visited the book shops and antique book stores. (No wonder that his library in Budapest became an invaluable informational centre for those who were interested in dance, generally traditional culture and other research fields of social sciences in Central and South-eastern Europe.

During our discussions with Martin we had two frequent topics concerning the methodology of research: visual documentation and the transcription of the collected dances. In Martin's opinion, for a folk dance researcher it is crucial and inevitable to establish a systematically arranged, scientific archive. I remember his words: "Our theories and interpretations in ethnochoreology are passing, they are doomed to be changed or disproved. The well documented folk dance data do not lose their value, and we can return to them any time if it is necessary." Following his conviction he developed such a systematic way of data collection, analysis and interpretation which makes his own collection and the material in the Folk Dance Archive of the Institute for Musicology of the Hungarian Academy of Sciences unsurpassed, from a methodological point of view. 
Our other common interest, the dance notation, concerned not the necessity of transcription, because we were both convinced that dance as an ephemeral phenomenon can be analysed and systematised only in transcribed form. The question was not "to use or not to use" a notation system, but "which notation system" we should use. We talked about the untenable situation that each of the countries dealing with folk dance research tries to create its own notation system instead of adopting a common one. As in other countries in the socialist camp, ethnochoreologists in the Folk Dance Department of the Institute of Folklore and Ethnography in Bucharest, working in almost total isolation, created their own system. It was at the beginning of the 1950s that Vera Proca-Ciortea (leader of the folk dance department) presented the system of Quick Transcription of Dance (QTD), which was appropriate for the indication of the structural and stylistic features of the Romanian folk dances in graphic notation. This quick and easy way of transcription, applicable directly on the field, parallel with the dance, enabled us to create an overall and simultaneous picture about our researched dance. Consequently, almost the whole archive in our institute was notated by this system. Labanotation was not unknown for us, but it seemed to be difficult and complicated. In contrast, Hungarian researchers have used Laban-Knust notation system since 1947. Once on the rare occasions when I visited Martin in Budapest in the Institute, he introduced me to Ágoston Lányi, who was expert on kinetography Laban. Transcription of dances was his everyday practice. As they told, the point is not the graphic representation of the movement, but its understanding, interpretation, and the selection of the most appropriate graphic signs. So in their transcriptions on the Hungarian dance tradition they selected those movement elements which are significant from the typological, structural and stylistic points of view and neglected the insignificant ones. Therefore, a kinetographer must know the dances very well, in order to be able to decide the significance of the movements in the context of the given motive or other structural elements. Collaboration between Martin and Lányi resulted in the full length-transcription of a surprisingly great number of traditional dances. (Martin himself was an expert on Labanotation and practiced it frequently, but he preferred spending more time and energy on fieldwork and dance analysis.) As I see, the holistic way of dance research as Martin practiced it and the graphic transcription of dances by Labanotation as Lányi made it, were two unique, complementary and interdependent activities, which happens rarely in ethnochoreology. It is even rarer that one ethnochoreologist unites the two abilities in himself.

\section{9, THE FIRST JOINT FIELD RESEARCHES WITH MARTIN}

It was the year 1969 when I had the opportunity to do field research with Martin several times. First we were together in Moldva, in Vaslui county in January. In spite of the difficult conditions, the harsh cold, it was a positive experience for me. I could realise how well Martin adapted to the difficulties, if not with ease, but with enough stoicism. I was surprised by the diversity of his interest, which was reflected in the research material he collected. In the new cultural sphere and theme, (symbolism and structure of the masked dances), he discovered such details which drew our attention to the comparative approach. 
On the same occasion we recorded on film the dance named "above the stick" (peste băț), existing in the Hungarian tradition more or less in the same form. The second common field work took place in county Alba, in the villages Pacalka and Magyarlapád. Our common interest was the dance cycle consisting of different dances, combined into one fixed series. The local name of the cycle was Haidău (hajduch dance) containing the following dances: de sărit, de purtat, de ponturi cu fete and hârțag. We started from Bucharest by a minibus with two wooden benches opposite to each other. After so much time I cannot remember what we spoke of in detail, but I recall that we were speaking and singing without stopping. We recalled all the purtata and slow dance melodies we knew, accompanied by stamping and imitating the figures by fingers. We had the hottest debate about the "origin" of the Transylvanian music and dance appropriated by both Romanians and Hungarians. Difference between our opinions stemmed from the interpretation of the historical data connected to lad's dance and especially caluser. Our discussion covered the purtat, slow dance and at last the invirtita. This was the first case when we thought of the necessity of a joint Romanian-Hungarian research project in some villages with mixed inhabitants, in order to settle this debate. From our debates and the common field work I concluded that he attached significance to the outstanding dancing individualities with great competence. So, for him the investigation of a local community could never end. Returning to the same settlement, making continuous research with the same dancers in the community were the basic principles for him. It is proved by the monograph about Mátyás István Mundruc, a dancer from Magyarvista (Vistea), whose dance knowledge was examined by Martin over many years.

\section{PLANNING JOINT PROJECTS}

In 1969 Romania entered an extreme, nationalist period focusing on cultural unity and hegemony. In this political context we, ethnochoreologists in the academic institute concentrated on the national features of folk dances and ignored the dances containing stylistic and structural elements not "purely Romanian". In this spirit, we neglected the dances of Hungarians and other nationalities. We did not collect dances in Transylvania, considering that it is the task of the Folklore Archive in Cluj or of the Hungarians in general. The Hungarian ethnochoreologists' standpoint about the concept of "cultural property" was totally dissimilar. The difference rooted in the debate between us about the attribution of the cultural elements to one or the other national cultures. This is a kind of pseudoproblem, which occurs in many places of the world. It may always lead to a conflict if the communication and confrontation is going on at the political and not at the scientific level. Martin and I were convinced that the conclusions in this debate between the choreographers and researchers will always be false if they forget that the Romanian and Hungarian peoples were living in the same cultural sphere, bearing the same cultural elements through the centuries. Based on the mutual respect and friendship between us with Martin I suggested a joint research program among the concerned nationalities, in villages of mixed (Romanian, Hungarian, Gypsy) population. The aim would have been to discover and explain how interference could come into being in a cultural complex maintained by 
different co-existing peoples in a common territory. We planned to reveal the different, frequently conflicting perceptions of the concerned local musicians and dancers.

In 1969 we submitted a joint proposal with Martin to the Romanian Scientific Academy. It was a reckless initiative at a time when all kinds of individual ideas were forbidden. The secretary of the academy listened to us attentively and then, turning to me, he stated the judgement: it is an individualistic project, losing the political directions and aims, thus it is not worth supporting. As a consequence, I almost lost my job in the institute and Martin could not come to Romania for field research for a long time.

\section{COOPERATION WITH MARTIN \\ IN THE INTERNATIONAL COUNCIL FOR FOLK MUSIC (IFMC)}

As one of the serial meetings in the framework of the Terminology Study Group of the IFMC on 13-18 of September 1976, we met in Zaborów (Poland). This time we had a double objective. On the one hand, we aimed at summarising the results of our efforts to define the principals of structural analysis and to establish its methodology. On the other hand, we wanted to outline a plan dealing with the theory and methods of the cross-cultural dance research in Europe. This time I worked with Martin and Eva Kröschlova on the definition of "phrase" as a structural unit above the motive-level. Besides, together with Martin we did the proofreading of a chapter on dance and music relationship. We made some corrections in the text and enriched the list of examples from our own collections. I could experience again Martin's extraordinarily rich and profound knowledge about this and other topics which we dealt with in our discussions there.

\section{OUR LAST MEETING WITH MARTIN}

Our last meeting took place on 26-27 June 1978, on the occasion of the Danube Folklore Festival in Kalocsa. There were a lot of ensembles from Hungary and the countries along the Danube. We had long discussions in the jury, so unfortunately I had not much time for personal conversation with Martin. We postponed it to a later occasion, which never came. In 1979 I managed to escape from Romania and settle in Denmark. In 1980, it would have been a new occasion for our meeting, but it could not be implemented. That year the Dance Museum in Stockholm organised a conference, where mostly the members of the IFMC Terminology Study Group were invited. As I had a "political refugee" status at that time, the chair person of the study group (privately) asked me not to participate the meeting, in order to avoid the "conflict situation". (Meaning that the majority of the participants came from the "socialist camp", including the chair person, who was living in Romania.) I am convinced that neither Martin nor the other participants could have known anything about this affair. 


\section{EPILOGUE}

Martin was the greatest and most talented ethnochoreologist of the second half of the 20th century. If I take into consideration his books, articles, and the themes of our personal discussions, the list is amazing. There are no such important fields of dance studies which he had not treated or only touched upon during his short carrier. To mention the most important ones: principles of the structural analysis, structural typology and classification of the dances, relations between dance and music, the process of dance creation, improvisation, tradition, learning, transmission, relationship between dancing individualities and communities, meaning and function of dances in various social contexts, historical layers of dance traditions in Hungarian and European context, relationship between dance and politics, dance as ethnic symbol, minority-majority questions and folk dances in the context of stage performance.

Martin died thirty years ago, but his life work remained inescapable, even if it is debatable in some points today. This is the most convincing evidence of his intellectual greatness as researcher and an extraordinary human person. I am happy that I could follow him on the ways of dance studies in some cases, which were opened to me by him.

\section{Remark of the translator:}

This recollection in English was made on the basis of Anca Giurchescu's text, published in the book titled "Az erdélyi táncmüvészet és tánctudomány az ezredfordulón" (Dance Art and Dance Studies in Transylvania at the Turn of the Milleneum) II, edited by Csongor KöNCZEI, Kolozsvár, 2014, pp. 11-29. It is a shortened version of Giurchescu's writing without the footnotes and literature for the purpose of this volume. Changes were made with the permission of the author. 